\title{
Effect of different culture conditions on the (twitching) displacement of Photobacterium damselae subsp. piscicida
}

\begin{abstract}
Photobacterium damselae subsp. piscicida (Phdp), etiological agent of photobacteriosis, is a non-motile bacterium. Notwithstanding, it is able to move on solid surfaces. The presence of pili-like structures on the bacterial surface has been recently described and being associated with twitching displacement by our team. The objective of this study was to modify some conditions (temperature, $\mathrm{pH}$, concentration of nutrients, salinity, solidification of the medium, surface roughness and presence of target cells of Phdp) to determine which ones promote motility on solid surfaces.

Lower temperatures $\left(\leq 18^{\circ} \mathrm{C}\right)$, alkaline and acidic environments and lacking salinity $(<0.5 \%)$ media had a negative effect on cell motility, while nutrient limitation did not affect the bacterial response. The best twitching motility was observed when Phdp was inoculated in medium with $0.2 \%$ agar and $\mathrm{pH} 7.0$. Also, interesting results were obtained on rough surfaces or by the addition of cellular debris of SAF-1 cell line to the medium.

According to the results, the "new" composition of the "twitching displacement" medium could be as follows: $3.7 \%(\mathrm{w} / \mathrm{v})$ brain-heart infusion broth (BHIB) supplemented with about $1.0 \%(\mathrm{w} / \mathrm{v}) \mathrm{NaCl}$ and $0.2 \%(\mathrm{w} / \mathrm{v})$ agar, with a final $\mathrm{pH}$ of 7.0 , and maybe, scrape petri dishes and add debris of SAF-1 cells 1:2-factor dilution to medium. If bacterial strains are incubated at $22-25^{\circ} \mathrm{C}$ for three days, a good response should be achieved in terms of fimbriae production.
\end{abstract}

Keywords: photobacterium damselae subsp. Piscicida, twitching, bacterial displacement, culture media
Volume 4 Issue 4 - 2017

\author{
Vega Belinda,' Ramos-Vivas José, ${ }^{2}$ Bravo \\ Jimena,' Acosta Begoña, ${ }^{3}$ Lázaro-Díez María, ${ }^{2}$ \\ Acosta Félix' \\ 'Grupo de Investigación en Acuicultura (GIA), Universidad de \\ Las Palmas de Gran Canaria, Spain \\ ${ }^{2}$ Servicio de Microbiología, Instituto de Investigación Marqués de \\ Valdecilla IDIVAL, Spain \\ ${ }^{3}$ Instituto Universitario de Sanidad Animal, Spain
}

Correspondence: Félix Acosta Arbelo, Grupo de Investigación en Acuicultura (GIA), Instituto Ecoaqua, Universidad de Las Palmas de Gran Canaria, PCTM, Spain, Email elix.acosta@ulpgc.es

Received: April 12, 2017 | Published: April 28, 2017
Abbreviations: Phdp, photobacterium damselae subsp.
piscicida; ATCC, american type culture collection; spp., species;
Subsp., subspecies; PBS, phosphate buffered saline solution; BHIB,
brain-heart infusion broth; BHIA, brain-heart infusion agar; SAF-1,
cell line from sparus aurata fin; NaCl, sodium chloride; CV, crystal
violet; PCR, polymerase chain reaction; RT, room temperature;
OD600, optical density at $600 \mathrm{~nm}$; $\mathrm{p}, \mathrm{p}$-value; w/v, weight/volume; $\mathrm{ml}$, milliliter; $\mathrm{nm}$, nanometre; $\mathrm{h}$, hour; ${ }^{\circ} \mathrm{C}$, degree celsius; $\%$, percent

\section{Introduction}

Photobacterium damselae subsp. piscicida (Phdp), which belongs to the family Vibrionaceae, is a pleomorphic Gram-negative bacterium, with bipolar staining, non-motile and halophilic. ${ }^{1,2}$ It grows at $15-30^{\circ} \mathrm{C}$, but the disease caused by this organism usually occurs when water temperatures are over $20^{\circ} \mathrm{C}$.

The etiological agent of fish photobacteriosis or pasteurellosis ${ }^{3}$ is an important pathogen affecting different fish species in Europe, Japan, USA and Mediterranean countries. ${ }^{4,5}$ It first appeared in USA in 1963 affecting wild white perch (Morone americanus) and striped bass (Morone saxatilis). ${ }^{6}$ Afterwards, it caused serious economic losses in aquaculture in Japan $^{7}$ and from the early 1990s began to spread across Europe, becoming a major problem in the global marine aquaculture.

Different studies reveal that Phdp has virulence factors involved in its pathogenesis: presence of a polysaccharide capsular layer ${ }^{8,9}$ plasmid-encoded virulence factors, ${ }^{10}$ iron uptake mechanisms, ${ }^{11}$ proteins with apoptotic activity, ${ }^{12}$ other enzyme activities, ${ }^{13,14}$ and resistance to blood serum of several fish species. ${ }^{15}$

"Twitching motility", term introduced is a kind of motion mediated by a proteinaceous and filamentous structure called TypeIV fimbriae or pili. ${ }^{16,17}$ It is located on the surface of many Gramnegative and Gram-positive bacteria, at one or both poles. ${ }^{18-20}$ And also, it is involved in surface adhesion and colonization, ${ }^{21-23}$ tropism determination, ${ }^{24}$ biofilm formation, ${ }^{23}$ genetic material uptake ${ }^{21}$ and virulence of bacteria. ${ }^{25-27}$ Fimbriae expression is controlled by transcriptional and post-transcriptiona ${ }^{28}$ and is influenced by several factors: bacterial growth rate, ${ }^{29}$ culture medium composition, ${ }^{30,31}$ temperature, ${ }^{32} \mathrm{pH}$ and osmolarity. ${ }^{33} \mathrm{So}$, it is a complex and unstable process and its levels are heterogeneous, frequently becoming lost. ${ }^{34}$

Recently, the presence of surface appendages similar to pili on Phdp (Figure 1) and the ability of this pathogen to move on solid surfaces have been described by our team..$^{35}$ Thus, we aim to go into detail about this subject, starting by studying and determining what factors and environmental conditions affect twitching displacement of Photobacterium damselae subsp. piscicida. Identifying these parameters should contribute to a better understanding of the correlation between the adherence capabilities and the pathogenicity of this bacterium. 


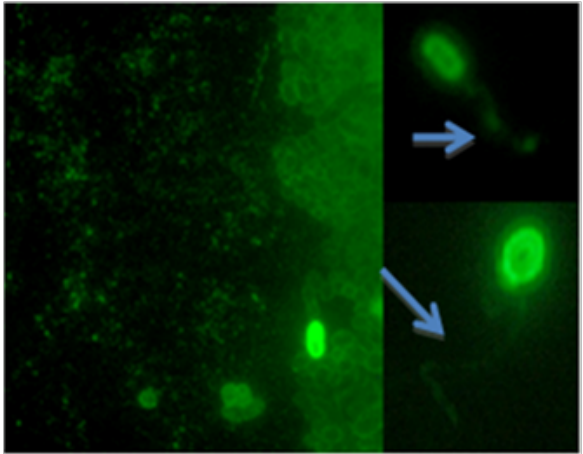

Figure I Immunofluorescence image of Phdp after motility assay. The bacteria was labeled with polyclonal antibody against Phdp and finally marked with Alexa 488antirabbit. The photo was taken in an Epi-fluorescence microscope Olympus BX43.

$\rightarrow$ pili-like structure.

\section{Material and methods}

Ethical approval is not required by a specific committee since animals has not been used in the present study for research purposes.

\section{Bacterial strains}

The five Photobacterium damselae subsp. piscicida strains used in this study are listed in Table 1. These bacteria were verified by biochemical and PCR tests and preserved in brain-heart infusion broth (BHIB-1.5) with $1.5 \% \mathrm{NaCl}$ and $25 \%$ glycerol at $-80^{\circ} \mathrm{C}$ until use.

Table I Bacterial strains used in this study

$\begin{array}{llll}\text { Phdp C2 } & \text { Gilthead seabream (Sparus aurata) } & \text { Spain, 1997 } & 55 \\ \text { Phdp 94/99 } & \text { Gilthead seabream (Sparus aurata) } & \text { Spain, 1999 } & 55 \\ \text { PhdpDI2I } & \text { Gilthead seabream (Sparus aurata) } & \text { Spain, 1991 } & 56 \\ \text { PhdpPP3 } & \text { Yellowtail (Seriolaquinqueradiata) } & \text { Japan } & \\ \text { Phdp ATCC 179II } & \text { White perch (Roccus americanus) } & \text { USA, I964 } & 6\end{array}$

\section{Prior to experiment}

The strains were routinely cultured in brain-heart infusion agar (BHIA-1.5) supplemented with $1.5 \% \mathrm{NaCl}$ and incubated at $22^{\circ} \mathrm{C}$ for 24hours. For experiments, 1-5 colonies of each strain were passed to $10 \mathrm{ml}$ of brain-heart infusion broth (BHIB-1.5) supplemented with $1.5 \% \mathrm{NaCl}$ and incubated at room temperature (RT), in darkness for $24 \mathrm{~h}$. When the medium was turbid (OD600 0.45$)$, it was diluted 1:100 with sterile phosphate buffered saline (PBS) solution, becoming the inoculum of the experiments.

\section{“Twitching displacement" medium}

The composition of the medium used to the experiments was brainheart infusion broth supplemented with $1.5 \% \mathrm{NaCl}$ and $0.3 \%$ agarose D-1 Low EEO (CONDA, Pronadisa). It was sterilized at $120^{\circ} \mathrm{C}$ for 20minutes, prepared and poured into Petri dishes the day before the experiment and kept in darkness at RT until use.

\section{Displacement assays}

After preparing everything, we proceeded to the inoculation of the media. To do this, sterile flat toothpicks were immersed into the bacterial suspensions for about 5 seconds and inoculated in three points into the agar to touch the plate underneath the agar, being removed after 1-2seconds. Afterwards, it was incubated for 48 and 72 hours in darkness.
The length of bacterial shifts from inoculation point was measured after 2 and 3days of incubation in every experiment to determine what environmental conditions favor "twitching motility". These conditions are detailed below.

\section{Temperature of incubation}

The temperatures of incubation studied were 18, 20, 22 (reference temperature) and $25^{\circ} \mathrm{C}$. And furthermore, some agar plates were kept at $4{ }^{\circ} \mathrm{C}$ for 3 and 7 days and later, inoculated and incubated at $22^{\circ} \mathrm{C}$ for other 2 and 3 days.

\section{pH}

The culture medium was prepared in the same conditions described above and the $\mathrm{pH}$ was adjusted with phosphate buffer to a final $\mathrm{pH}$ of $6,7,8$ and 9 .

\section{Concentration of nutrients}

The quantity of brain-heart infusion broth was reduced by half and a quarter to evaluate the bacterial response when the availability of nutrients decreases.

\section{Salinity of the medium}

For this assay, the medium was supplemented with $0,0.5,1,1.5,2$ and $2.5 \%$ of sodium chloride $(\mathrm{NaCl})$. Also, we inoculated in "salinity medium" with $0 \% \mathrm{NaCl}(0.3 \%$ agarose, $0.1 \%$ yeast extract, $0.4 \%$ peptone; w/v).

\section{Agar concentration of the medium}

$0.3 \%$ agar added to the medium was compared to 0.2 and $0.4 \%$ to check whether the degree of solidification of the medium facilitates or curbs bacterial motility.

\section{Scraping petri dishes}

The objective of this test was to observe whether rough surfaces benefit the biofilm formation and cell attachment, as well as compare the motility on rough and smooth surfaces. It was carried out under sterile conditions before serving the "motility" medium by using sterile scissors to draw a "W" on the plate in every direction.

\section{Cell debris in the medium}

Debris of SAF-1 cells was added in the medium in order to generate tropism, previously knowing that Phdp is able to adhere to, invade and survive within these cells. ${ }^{36}$ This cell line consists of fibroblastic cells from fin of gilthead seabream (Sparus aurata). ${ }^{37}$ Cells from culture bottles were diluted with PBS to 0.409 optical density at $600 \mathrm{~nm}$. Next, it was diluted by a factor of 1:2, 1:4 and $1: 8.10 \mathrm{ml}$ of each dilution were mixed with $200 \mathrm{ml}$ of medium.

\section{Crystal violet staining}

After three days of incubation, agar was carefully removed from petri dishes to show the bacterial growth and shift on the plate beneath the agar. Loose cells and agar remains were washed with distilled water and then, the attached bacteria were stained with crystal violet (CV) solution $(0.7 \% \mathrm{w} / \mathrm{v})$. Twelve minutes later, it was washed and air dried. Finally, we could observe the bacteria fixed to the plate.

\section{Statistical analysis}

Analyses were produced on IBM SPSS Statistics 22.0 (IBM Corp.), using general linear models: multivariate (posthoc tests: Tukey, Duncan and Hochberg) to compare the "different groups" of each assay for both data collection days (days 2 and 3 of incubation) 
separately and univariate to analyse the differences on motility between "days 2 and 3 of incubation" for each group. Models indicate significance when $\mathrm{p} \leq 0.05$.

\section{Results}

\section{Temperature of incubation}

Strains C2 and ATCC 17911 developed displacement at all temperatures tested, with no significant difference $(\mathrm{p}>0.05)$. The same for strains PP3 and DI21when Phdp was incubated for 3days, but on the second day of incubation, we could see no growth and no motility at $18^{\circ} \mathrm{C}(\mathrm{p}>0.05)$. Nevertheless, strain $94 / 99$ had not motion at $18^{\circ} \mathrm{C}$ (day 2) nor when it was previously kept cold for a week (days 2 and 3) $(p>0.05)$ (Figure 2). There were no significant differences between days of incubation either ( $>0.05)$, except for groups " 7 days at $4{ }^{\circ} \mathrm{C}$ " $\left(\right.$ strain DI21) $(\mathrm{p}<0.01)$ and " $18^{\circ} \mathrm{C}$ " (strain ATCC 17911) $(\mathrm{p}<0.04)$ (Figure 2).

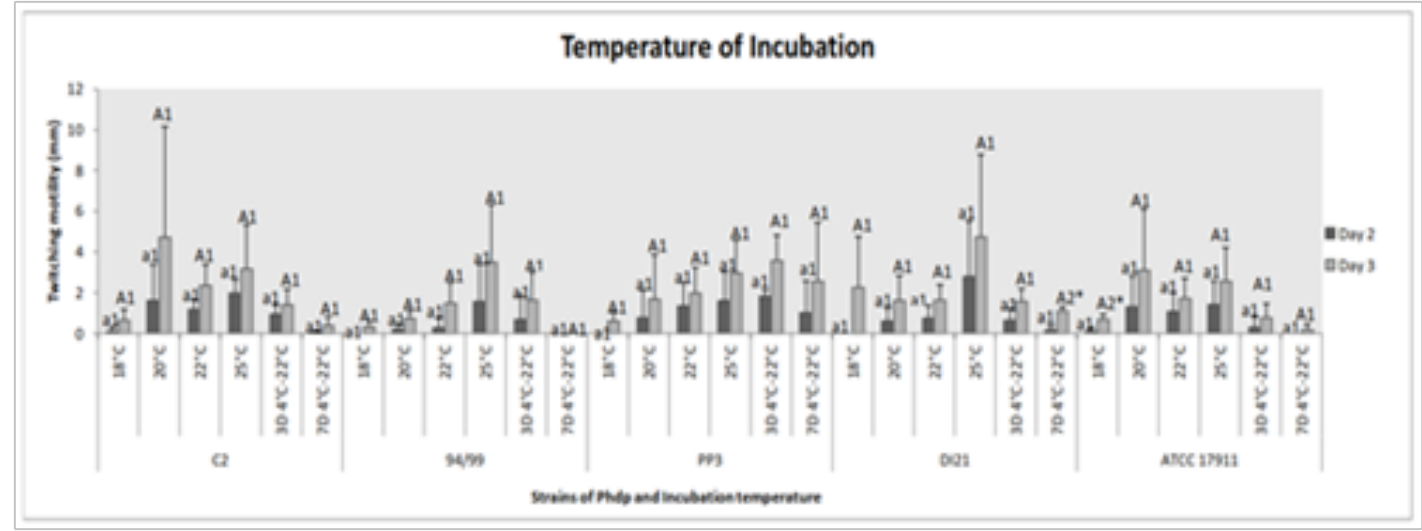

Figure 2 Effect of temperature of incubation on twitching motility of the Phdp strains tested: C2, 94/99, PP3, DI2I and ATCC I79II.

Small letters: Compare "groups" after $48 \mathrm{~h}$ of incubation

Capital letters: Compare "groups" after $72 \mathrm{~h}$ of incubation

Numbers: Compare "days of incubation" of each group

*Indicates that there are statistically significant differences

pH

After 2days of incubation, all the strains only swelled and moved at $\mathrm{pH} 7$, with significant difference in the case of $\mathrm{C} 2(\mathrm{p}<0.005)$ and DI21 strains $(\mathrm{p}<0.05)$. After 3days, history repeated itself for strains C2, 94/99 and ATCC 17911, with significant difference for the first one $(\mathrm{p}<0.0001)$; while the other strains had displacement at different $\mathrm{pH}$, although with significant difference between $\mathrm{pH} 7$ and other $\mathrm{pH}$ values (strain PP3) $(\mathrm{p}<0.005)$ (Figure 3). Comparing days of incubation, there were significant differences for groups " $\mathrm{pH} 7$ " (strain C2) $(\mathrm{p}<0.03)$ and "pH 6" (strain DI21) $(\mathrm{p}<0.04)$ (Figure 3).

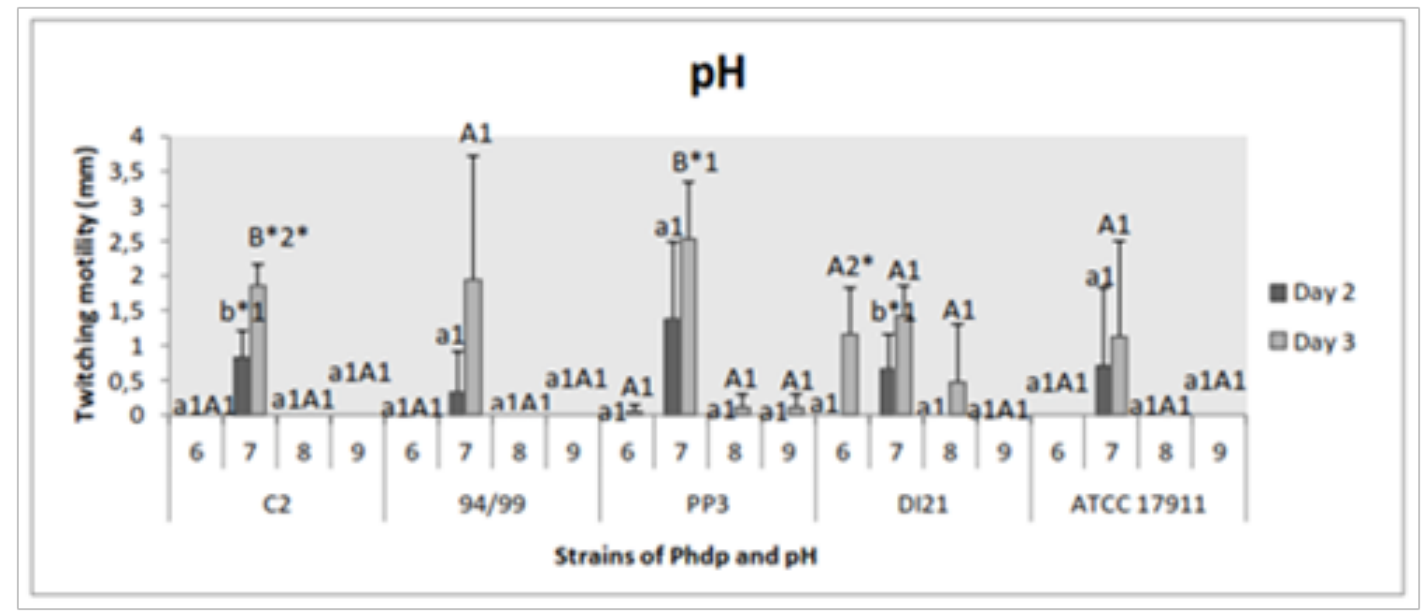

Figure 3 Effect of pH on twitching motility of the Phdp strains tested: C2, 94/99, PP3, DI2 I and ATCC I79| I.

Small letters: Compare "groups" after 48h of incubation.

Capital letters: Compare "groups" after $72 \mathrm{~h}$ of incubation.

Numbers: Compare "days of incubation" of each group.

*Indicates that there are statistically significant differences. 


\section{Concentration of nutrients}

Bacteria showed displacement at all concentrations of nutrients tested, with no statistically significant differences between groups $(p>0.05)$ and between days of incubation ( $p>0.05)$. These results were obtained in all cases (Figure 4).

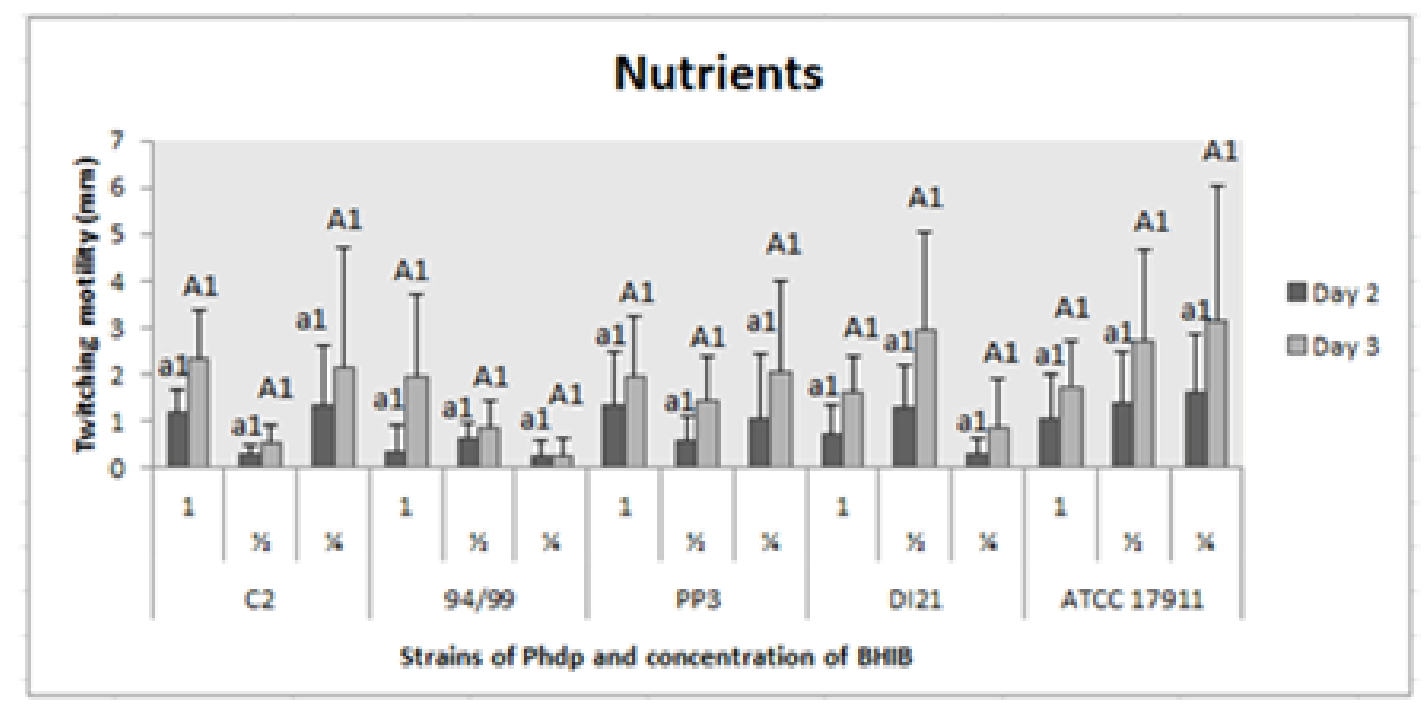

Figure 4 Effect of nutrients on twitching motility of the Phdp strains tested: C2, 94/99, PP3, DI2 I and ATCC I79I I.

Small letters: Compare "groups" after 48h of incubation.

Capital letters: Compare "groups" after $72 \mathrm{~h}$ of incubation.

Numbers: Compare "days of incubation" of each group.

*Indicates that there are statistically significant differences.

\section{Salinity of the medium}

Regarding strain $\mathrm{C} 2$, we found significant difference on displacement between bacteria inoculated in medium supplemented with $1 \% \mathrm{NaCl}$ and media containing no added $\mathrm{NaCl}(\mathrm{p}<0.01)$. Between groups " $\mathrm{NaCl}$ free-salinity medium", wherein bacteria had no growth or motility, and "twitching motility medium with $0 \%$
$\mathrm{NaCl}$, , between every group and between days of incubation, there were no significant differences $(\mathrm{p}>0.05)$ (Figure 5). The following strain, 94/99, had no significant difference between groups $(\mathrm{p}>0.05)$ and between days of incubation ( $p>0.05)$, just the same as strains PP3, DI21 (except between days 2 and 3 of incubation in Group " $1 \%$ " $(\mathrm{p} \leq 0.05))$ and ATCC 17911 (except between days in Group "2.5\%" $(\mathrm{p}<0.01))$ (Figure 5).

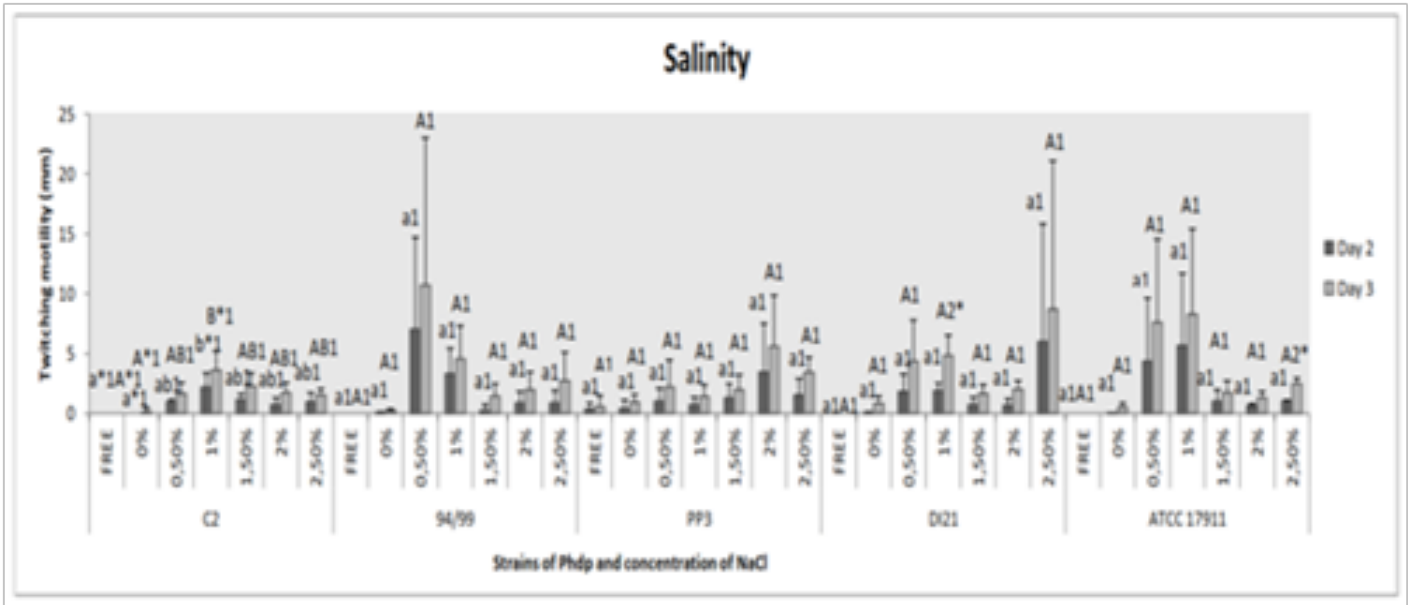

Figure 5 Effect of salinity of the medium on twitching motility of the Phdp strains tested: C2, 94/99, PP3, DI2I and ATCC I79I I.

Small letters: Compare "groups" after $48 \mathrm{~h}$ of incubation

Capital letters: Compare "groups" after $72 \mathrm{~h}$ of incubation

Numbers: Compare "days of incubation" of each group

*Indicates that there are statistically significant differences 


\section{Agar concentration of the medium}

Significant increased motility was observed when the concentration of agar was lower $(0.2 \% \mathrm{w} / \mathrm{v})$ in strains $94 / 99(\mathrm{p}<0.02)$, DI21 $(\mathrm{p} \leq 0.05)$ and ATCC $17911(\mathrm{p} \leq 0.05)$; the other two strains also moved larger in $0.2 \%$ agar-medium, but with no statistical significance $(p>0.05)$ (Figure 6). Significant difference between days of incubation was not detected $(\mathrm{p}>0.05)$ (Figure 6).

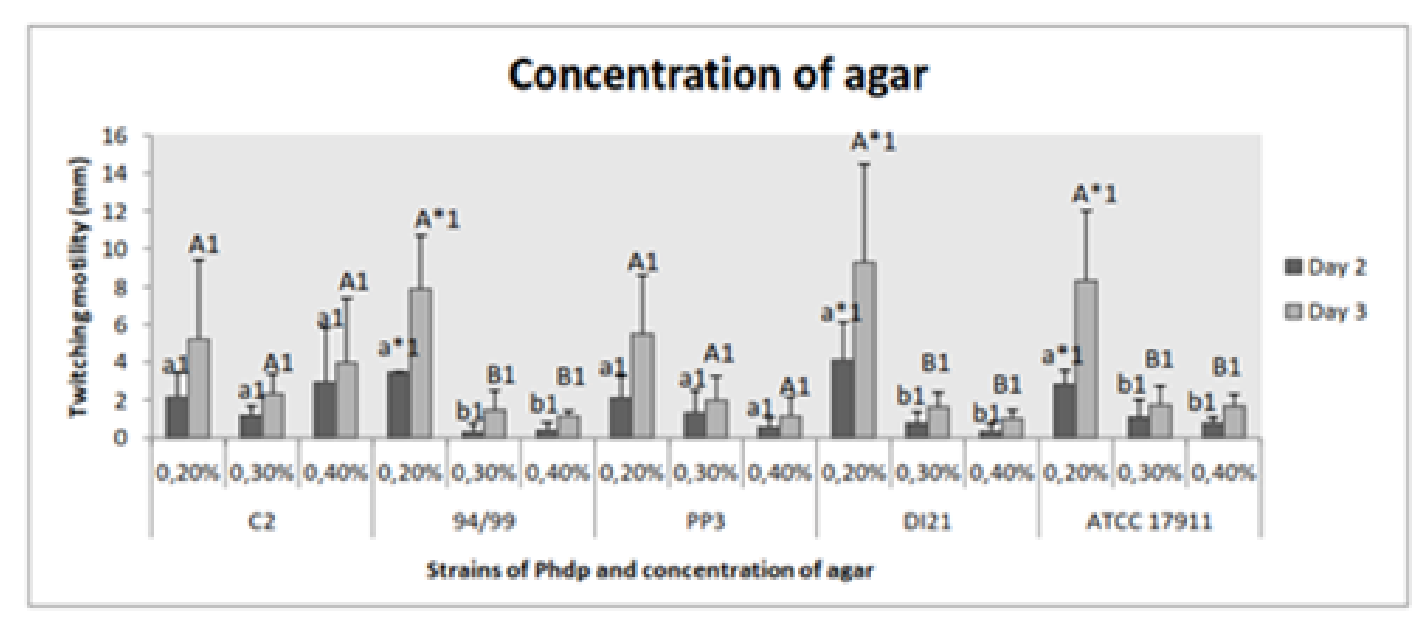

Figure 6 Effect of agar concentration of the medium on twitching motility of the Phdp strains tested: C2, 94/99, PP3, DI2I and ATCC I79II.

Small letters: Compare "groups" after $48 \mathrm{~h}$ of incubation.

Capital letters: Compare "groups" after 72h of incubation.

Numbers: Compare "days of incubation" of each group.

*Indicates that there are statistically significant differences.

\section{Scraping petri dishes}

Scrape the petri dishes or not was not statistically different $(\mathrm{p}>0.05)$. However, displacement was slightly higher for all strains

in the first case. We could always notice that the bacterial shifts were larger on the third day of incubation as in all assays, except when there was no motility; at this time, with no significant difference ( $p>0.05)$ (Figure 7).

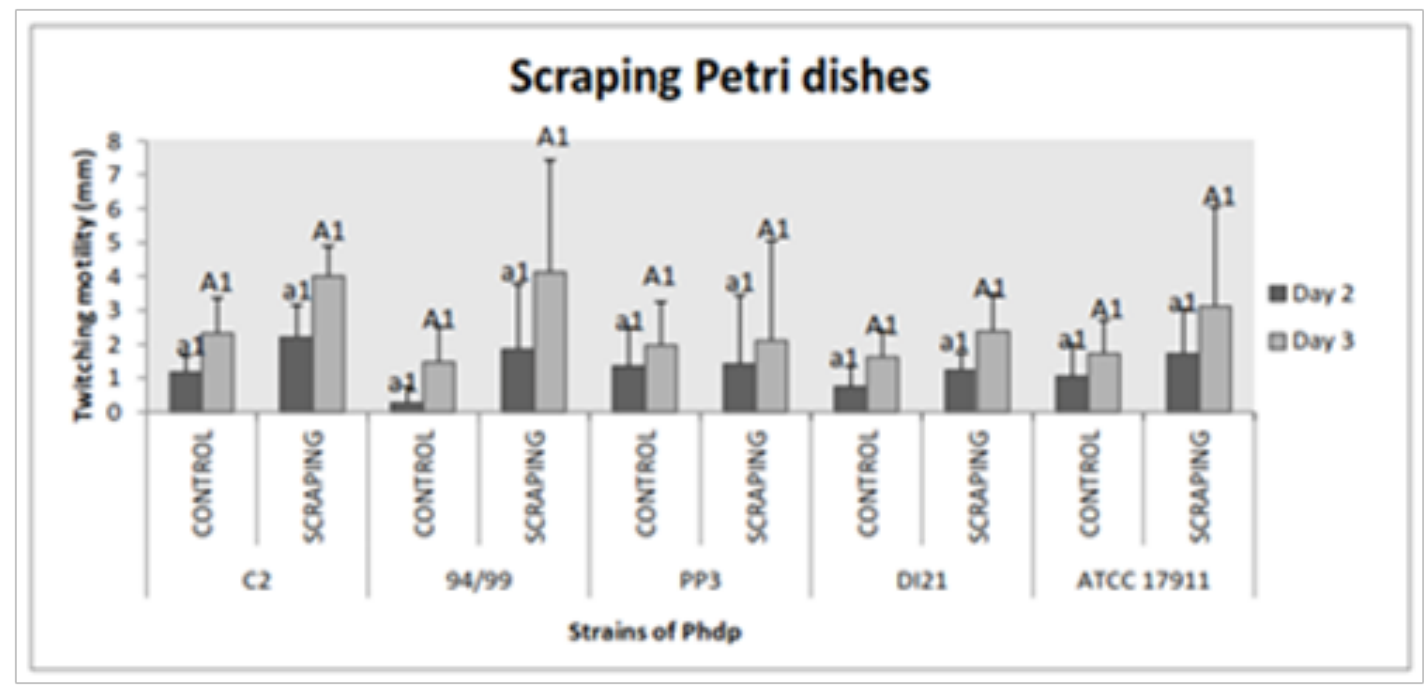

Figure 7 Effect of scraping the area of bacterial shift and attachment on twitching motility of the Phdp strains tested: C2, 94/99, PP3, DI2I and ATCC I79II. Small letters: Compare "groups" after $48 \mathrm{~h}$ of incubation

Capital letters: Compare "groups" after $72 \mathrm{~h}$ of incubation

Numbers: Compare "days of incubation" of each group

*Indicates that there are statistically significant differences

\section{Cell debris in the medium}

There were no significant differences between the groups "control" and "presence of cells in the medium" ( $p>0.05)$ and between the different dilutions of cells $(\mathrm{p}>0.05)$, for any strain. In the case of strains 94/99, DI21 and ATCC 17911, displacement best 
values seemed to be associated with presence of cell but in a lesser proportion, whereas for strain PP3 it was the opposite, displacement was not observed at 1:8 factor- dilutions. Strain $\mathrm{C} 2$ had groups with similar results $(\mathrm{p}>0.05)$ (Figure 8). Significant differences between days of incubation in groups "control" $(94 / 99$ and DI21) $(\mathrm{p} \leq 0.05)$ and "1:4 factor-dilution" (DI21) $(\mathrm{p}<0.01)$ were obtained (Figure 8).

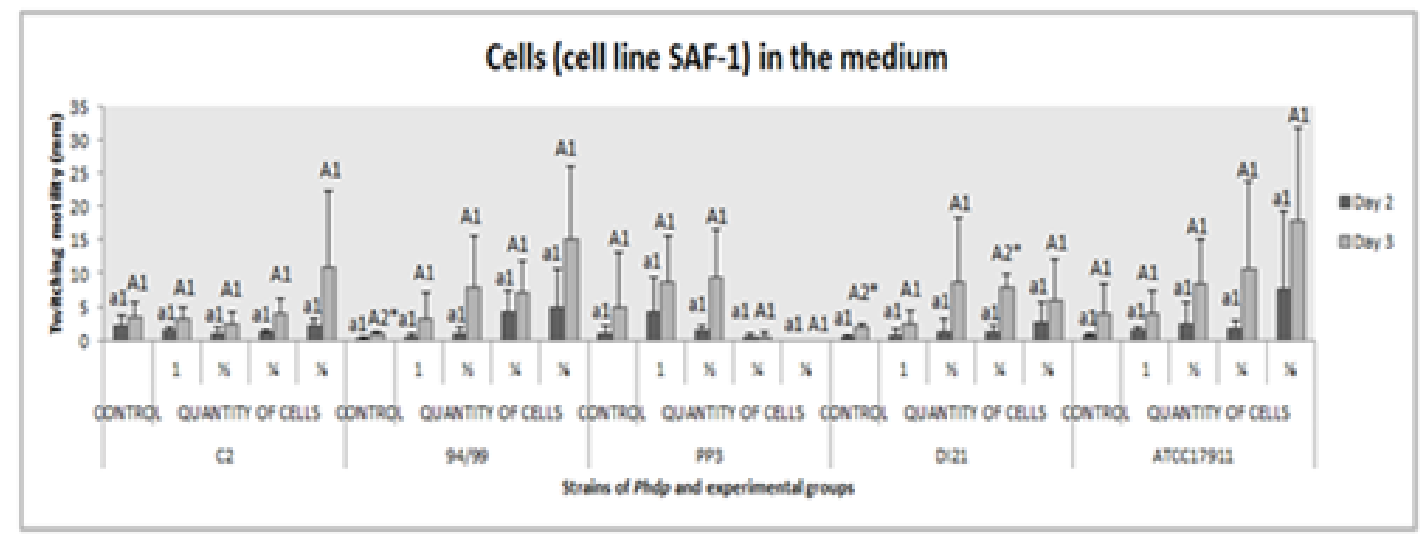

Figure 8 Effect of presence of cell debris in the medium on twitching motility of the Phdp strains tested: C2, 94/99, PP3, DI2I and ATCC I79II.

Small letters: Compare "groups" after $48 \mathrm{~h}$ of incubation

Capital letters: Compare "groups" after $72 \mathrm{~h}$ of incubation

Numbers: Compare "days of incubation" of each group

*Indicates that there are statistically significant differences

\section{Discussion}

For various reasons, many authors have reached the conclusion that low and high temperatures alter fimbriae expression; ${ }^{29,38,39}$ bearing in mind, of course, that the meaning of low or high will depend on the bacteria (and its genetics). In our work, the best performance was obtained between 22 and $25^{\circ} \mathrm{C}$. At lower temperatures, especially at $18^{\circ} \mathrm{C}$, bacteria did not always grow and develop displacement. Studied the adhesion of a marine bacterium to surfaces and the number of attached bacteria was proportional to the density of suspended bacteria at $12^{\circ} \mathrm{C}$ to $14^{\circ} \mathrm{C},{ }^{40}$ on the other hand, at $25^{\circ} \mathrm{C}$, only a few bacteria were attached to the surface, despite a high culture density. Nevertheless, we did not measure the number of bacteria, but the displacement on the solid surface. As stated in the introduction of this article, temperature and media affect fimbria expression; this was observed while studying type 1 fimbriae in Escherichia coli K-12 and these effects appear to be independent: ${ }^{41}$ low temperatures slow down even shut down the fimbriae synthesis because that affects the promoters switching and fim genes; for E. coli, the optimal temperature seems to be between 37 and $41^{\circ} \mathrm{C}$, however, these temperatures are too high for Photobacterium damselae subsp. piscicida and $28^{\circ} \mathrm{C}$, which is the lowest temperature tested, is still high.

Expression of fim genes is slightly lower in alkaline and acidic environments than at neutral $\mathrm{pH}$, where it is maximal. Acidic environments also affect the transcription of fim promoters. ${ }^{33}$ So, this could explain the results obtained in this experiment. Twitching displacement happened at $\mathrm{pH}$ 7.0. At other $\mathrm{pH}$ values, it was only and occasionally observed in two strains, after three days of incubation and considerably fewer compared to that developed at neutral $\mathrm{pH}$. But about the adhesion ability, the results achieved with an unidentified motile Gram-negative rod was no difference at $\mathrm{pH} 7.4$ and $8.6^{40}$ and with Vibrio spp. were a maximal adhesion at $\mathrm{pH} 8.2-8.5 .{ }^{42}$ The repressing effect on transcription of these genes at low $\mathrm{pH}$ is increased when osmolarity is moderate to high in Uropathogenic Escherichia coli $;{ }^{33}$ but Photobacterium damselae subsp. piscicida is a marine fish bacterium and can tolerate high $\mathrm{NaCl}$ concentrations, so it could be expected that its performance would be different.

Fimbriae expression depends on specific growth rate, which is independent of the growth-limiting nutrient used. ${ }^{29}$ On the other hand, in this study, the quantity of nutrient in the medium was reduced, observing perhaps a slight and not significant decrease in twitching displacement of strains 94/99 and DI21 at low concentration of nutrients. Nevertheless, with all the data, we think we can say that nutrient limitation does not seem to significantly affect phenotypically. In the study of Fletcher and Floodgate, ${ }^{41}$ the peptone concentration did not affect the number of attached bacteria either, even if the levels used were greater than the natural organic nutrient concentrations in seawater. On the other hand, Gally et al., ${ }^{41}$ observed that fimbria synthesis was slower in defined rich medium than minimal medium and can vary and be control by levels of aliphatic amino acids (alanine, isoleucine, leucine, valine).

No twitching displacement in $\mathrm{NaCl}$-free culture media can be explained by the necessity of $\mathrm{NaCl}$ for Phdp to grow and accordingly, to move. This result contrasts with others, where an increased osmolarity reduces fimbriae expression; ${ }^{33}$ however, the adhesion of Vibrio spp., other marine bacteria, to mucus-coated glass slides is higher when the bacterial cells are incubated in seawater $(3.5 \% \mathrm{NaCl})$ than in saline solution and PBS. ${ }^{42}$

Fimbriae production by bacteria is greater in broth than agar $(1.5 \%)$ cultures $^{38}$ and therefore, displacement is better on rather soft and wet surfaces $(0.3 \%$ agar $)$ than on relatively firm and dry surfaces $(1.5 \%$ agar $){ }^{43}$ We agree with this statement. Nevertheless, Liu et al., ${ }^{44}$ observed a better twitching displacement in 1.2-1.6\% agar plates after testing agar concentrations ranging from 0.8 to $2.0 \%$.

Slightly greater displacement was got on rough surface, it is known that such surfaces favour the biofilm formation; ${ }^{45}$ after all, bacterial adhesion is affected by physic-chemical properties of both the surface and the bacteria cell wall, including its structural features, ${ }^{46-48}$ in this case, fimbriae. Also, Anselme ${ }^{49}$ showed a relationship between roughness and adherent bacteria number on polyurethane-coated glass 
plates preconditioned in seawater. Whitehead et al., ${ }^{50} \&$ Campoccia et al., ${ }^{51}$ studied this subject by testing different pits with specific diameter and depth, whereas in our assay, the marks were irregular on the plates and the results expressed as displacement and not bacteria number; in the first study, there was an increase of adherent bacteria number on rough surfaces, especially on the bottom of crevices, ${ }^{52}$ although the lowest number was obtained on the larger pit, but in the second one, no differences were observed. In addition, some authors have proposed that bacterial response to nanometer scale roughness is mediated by structures such as fimbriae..$^{48,49}$

Adding metals to the medium ( $\mathrm{Ca}, \mathrm{Co}, \mathrm{Cu}, \mathrm{Fe}$ and so on), ${ }^{53}$ exposing bacteria to tissue cells it interacts with and feels tropism towards ${ }^{54}$ as our work, are some methods employed in order to study and promote cell adhesion and twitching displacement. That is it, Phdp strain PP3 showed a slightly better displacement in culture media with a lot of cells; strains 94/99, DI21 and ATCC 17911 too, but a lower amount of added cells was enough and better; however, for the strain $\mathrm{C} 2$, media with or without cell debris did not make difference.

In conclusion, according to the results, the "new" composition of the "twitching displacement" medium could be as follows: $3.7 \%$ (w/v) BHIB supplemented with about $1.0 \%(\mathrm{w} / \mathrm{v}) \mathrm{NaCl}$ and $0.2 \%$ $(\mathrm{w} / \mathrm{v})$ agar, with a final $\mathrm{pH}$ of 7.0 , and maybe, scrape petri dishes and add debris of SAF-1 cells 1:2-factor dilution to medium. If bacterial strains are incubated at $22-25^{\circ} \mathrm{C}$ for three days, a good response should be achieved in terms of fimbriae production. Now, we must continue with the study of these pili-like structures recently discovered in Photobacterium damselae subsp. piscicida and their relationship to the ability of the bacteria to adhere and invade non-phagocytic cells, and their possible involvement in the development of immunity against Photobacterium damselae subsp. piscicida and the possible application of the same in vaccine formulations or as a therapeutic target. With this medium we can increase significantly the expression of such pili-like structures to work.

\section{Acknowledgements}

Dr. Acosta thanks to Fundación Ramón Areces for support this work by the Grant XVII Concurso Nacional para la adjudicación de Ayudas a la Investigación en Ciencias de la Vida y de la Materia (CIVP16A1810). Belinda Vega thanks to University of Las Palmas de Gran Canaria for suport with phD grant.

\section{Conflict of interest}

The author declares no conflict of interest.

\section{References}

1. Janssen WA Surgalla MJ. Morphology, physiology and serology of a Pasteurella species pathogenic for white perch (Roccus americanus). $J$ Bacteriol. 1968;96(5):1606-1610.

2. Magariños B, Romalde JL, Bandín I, et al. Phenotypic, antigenic and molecular characterization of Pasteurella piscicida strains isolated from fish. Appl Environ Microbiol. 1992;58(10):3316-3322.

3. Gauthier G, Lafay B, Ruimy R, et al. Small-subunit rRNA sequences and whole DNA relatedness concur for the reassignment of Pasteurella piscicida (Snieszko et al.) Janssen and Surgalla to the genus Photobacterium as Photobacterium damsela subsp. piscicida comb. nov. Int J Syst Bacteriol. 1995;45(1):139-144.

4. Romalde JL, Magariños B. Immunization with bacterial antigens: pasteurellosis. Dev Biol Stand. 1997;90:167-177.
5. Romalde JL. Photobacterium damselae subsp. piscicida: an integrated view of a bacterial fish pathogen. Int Microbiol. 2002;5(1):3-9.

6. Snieszko SF, Bullock GL, Hollis E, et al. Pasteurella sp. from an epizootic of white perch (Roccus americanus) in Chesapeake Bay tidewater areas. J Bacteriol. 1964;88:1814-1815.

7. Kusuda R, Yamaoka M. Etiological studies on bacterial pseudotuberculosis in cultured yellowtail with Pasteurella piscicida as the causative agent. I. On the morphological and biochemical properties. B Jpn Soc Sci Fish. 1972;38(12):1325-1332.

8. Magariños B, Bonet R, Romalde JL, et al. Influence of the capsular layer on the virulence of Pasteurella piscicida for fish. Microb Pathog. 1996;21(4):289-297.

9. Magariños B, Romalde JL, Noya M, et al. Adherence and invasive capacities of the fish pathogen Pasterella piscicida. FEMS Microbiol Lett. 1996;138(1):29-34.

10. Do Vale A, Silva MT, dos Santos NMS, Nascimento DS, Reis Rodrigues P AIP56, a novel plasmid-encoded virulence factor of Photobacterium damselae subsp. piscicida with apoptogenic activity against sea bass macrophages and neutrophils. Mol Microbiol. 2005;58(4):1025-1038.

11. Magariños B, Romalde JL, Lemos ML, et al. Iron uptake by Pasterella piscicida and its role in pathogenicity for fish. Appl Environ Microbiol. 1994;60(8):2990-2998.

12. Do Vale A, Marques F, Silva MT. Apoptosis of sea bass (Dicentrarchus labrax L.) neutrophils and macrophages induced by experimental infection with Photobacterium damselae subsp. Piscicida. Fish Shellfish Immunol. 2003;15(2):129-144.

13. Diaz-Rosales P, Chabrillón M, Arijo S, et al. Superoxide dismutase and catalase activities in Photobacterium damselae subsp. piscicida. J Fish Dis. 2006;29(6):355-364.

14. Naka H, Hirono I, Aoki T. Cloning and characterization of Photobacterium damselae subsp. piscicida phospholipase: an enzyme that shows haemolytic activity. J Fish Dis. 2007;30(11):681-690.

15. Acosta F, Ellis AE, Vivas J, et al. Complement consumption by Photobacterium damselae subsp. piscicida in seabream, red porgy and sea bass normal and immune serum. Effect of the capsule on the bactericidal effect. Fish Shellfish Immun. 2006;20(5):709-717.

16. Ottow JCG. Ecology, physiology and genetics of fimbriae and pili. Annu Rev Microbiol. 1975;29:79-108.

17. Strom MS. Lory S. Structure-function and biogenesis of the type IV pili. Annu Rev Microbiol. 1993;47:565-596.

18. Henrichsen J. The occurrence of twitching motility among Gramnegative bacteria. Acta Pathol Microbiol Scand B. 1975;83(3):171-178.

19. Henrichsen J. Twitching motility. Annu Rev Microbiol. 1983;37:81-93.

20. Kaiser D. Social gliding is correlated with the presence of pili in Myxococcus xanthus. P Natl Acad Sci USA. 1979;76(11):5952-5956.

21. Manning PA, Meyer TF. Type-4 pili: biogenesis, adhesins, protein export and DNA import. Proceeding of a workshop. Gene. 1997;192(1):1-198.

22. Boyd JM, Dacanay A, Knickle LC, et al. Contribution of Type IV Pili to the virulence of Aeromonas salmonicida ssp. salmonicida in Atlantic salmon (Salmo salar L.). Infect Immun. 2008;76(4):1445-1455.

23. Hadi N, Yang Q, Barnett TC. Tabei SMB. Bundle-Forming Pilus Locus of Aeromonas veronii vb. sobria. Infect Immun. 2012;80(4):1351-60.

24. Parkinson JS. Signal transduction schemes of bacteria. Cell. 1993;73(5):857-871.

25. Masada CL, LaPatra SE, Morton AW, et al. An Aeromonas salmonicida type IV pilin is required for virulence in rainbow trout Oncorhynchus mykiss. Dis Aquat Organ. 2002;51(1):13-25. 
26. Josenhans $\mathrm{C}$, Suerbaum $\mathrm{S}$. The role of motility as a virulence factor in bacteria. Int J of Med Microbiol. 2002;291(8):605-614.

27. Krukonis ES, DiRita VJ. From motility to virulence: sensing and responding to environmental signals in Vibrio cholerae. Curr Opin Microbiol. 2003;6(2):186-190.

28. Verdonck F, Cox E, Goddeeries BM. F4 fimbriae expressed by porcine enterotoxigenic Escherichia coli, an example of an eccentric fimbrial system? J Mol Microbiol Biotech. 2004;7(4):155-169.

29. Van der Woude MW, Arts PA, Bakker D, et al. Growth rate dependent synthesis of K99 fimbrial subunits is regulated at the level of transcription. J Gen Microbiol. 1990;136:897-903.

30. Girardeau JP, Dubourguier HC, Gouet P. Inhibition of K99 synthesis by L-alanine in enterotoxigenic Escherichia coli. J Gen Microbiol. 1982;128(3):463-470.

31. Girardeau JP, Dubourguier HC, Gouet P. Effect of the glucose and amino acids on expression of K99 antigen in Escherichia coli. J Gen Microbiol. 1982;128(10):2243-2249.

32. Van der Woude MW, Braster M, Van Verseveld HW, et al. Control of temperature-dependent synthesis of K99 fimbriae. FEMS Microbiol Lett. 1990;56(1-2):183-188.

33. Schwan WR, Lee JL, Lenard FA, et al. Osmolarity and $\mathrm{pH}$ growth conditions regulate fim gene transcription and type 1 pilus expression in uropathogenic Escherichia coli. Infect Immun. 2002;70(3):1391-1402.

34. Campal Espinosa AC, Junco Barranco JA, Arteaga Moré NO, et al. A general procedure for small-scale purification of fimbriae expressed by porcine enterotoxigenic Escherichia coli strains. Rev Colomb Biotec. 2008;10:122-131.

35. Remuzgo-Martínez S, Lázaro-Díez M, Padilla D, et al. New aspects in the biology of Photobacterium damselae subsp. piscicida: pili, motility and adherence to solid surfaces. Vet Microbiol. 2014;174(1-2):247-254.

36. Acosta F, Vivas J, Padilla D, et al. Invasion and survival of Photobacterium damselae subsp. piscicida in non-phagocytic cells of gilthead sea bream, Sparus aurata L. J Fish Dis. 2009;32(6):535-541.

37. Bejar J, Borrego JJ, Alvarez MC. A continuous cell line from the cultured marine fish gilt-head seabream (Sparus aurata L.). Aquaculture. 1997; 150:143-53.

38. Amano A, Sharma A, Sojar HT, et al. Effects of temperature stress on expression of fimbriae and superoxide dismutase by Porphyromonas gingivalis. Infect Immun. 1994;62(10):4682-4685.

39. Walker SL, Sojka M, Dibb-Fuller M, et al. Effect of $\mathrm{pH}$, temperature and surface contact on the elaboration of fimbriae and flagella by Salmonella serotype Enteritidis. J Med Microbiol. 1999;48(3):253-261.

40. Fletcher M, Floodgate GD An electron-microscopic demonstration of an acidic polysaccharide involved in the adhesion of a marine bacterium to solid surfaces. J Gen Microbiol. 1973;74:325-334.

41. Gally DL, Bogan JA, Eisenstein BI, et al. Environmental regulation of the fim switch controlling type 1 fimbrial phase variation in Escherichia coli $\mathrm{K}-12$ :Effects of temperature and media. J Bacteriol. 1993;175(19):6186-6193.
42. Balebona MC, Moriñigo MA, Faris A, et al. Influence of salinity and $\mathrm{pH}$ on the adhesion of pathogenic Vibrio strains to Sparus aurata skin mucus. Aquaculture. 1995;132:113-120.

43. W Zusman DR. The two motility systems of Myxococcus xanthus show different selective advantages on various surfaces. Proceedings of National Acad Sci USA. 1993;90(8):3378-3382.

44. Liu H, Kang Y, Genin S, et al. Twitching motility of Ralstonia solanacearum requires a type IV pilus system. Microbiol. 2001;147(pt 12):3215-3229.

45. Teughels W, Van Assche N, Sliepen I, et al. Effect of material characteristics and/or surface topography on biofilm development. Clin Oral Implan Res. 2006;17(Suppl 2):68-81.

46. Smets BF, Grasso D, Engwall MA, et al. Surface physicochemical properties of Pseudomonas fluorescens and impact on adhesion and transport through porous media. Colloids Surfaces B. 1999;14:121-139.

47. Camesano TA, Logan BE. Probing bacterial electrosteric interactions using atomic force microscopy. Environ Sci Technol. 2000;34(16):33543362 .

48. Bakker DP, Busscher HJ, Van Zanten J, et al. Multiple linear regression analysis of bacterial deposition to polyurethane coatings after conditioning film formation in the marine environment. Microbiol. 2004; 150(pt 6):1779-1784.

49. Anselme K, Davidson P, Popa AM, et al. The interaction of cells and bacteria with surfaces structured at the nanometer scale. Acta Biomater. 2010;6(10):3824-3846.

50. Whitehead KA, Colligon J, Verran J. Retention of microbial cells in substratum surface features of micrometer and sub-micrometer dimensions. Colloids Surfaces B. 2005;41(2-3):129-138.

51. Campoccia D, Montanaro L, Agheli H, et al. Study of Staphilococcus aureus adhesion on a novel nanostructured surface by chemiluminometry. Intern J Art Org. 2006;29(6):622-629.

52. Characklis WG. Fouling biofilm development: a process analysis Biotechnol and Bioeng. 1981;23(9):1923-1960.

53. Cruz LF, Cobine PA, De La Fuente L. Calcium increases Xylella fastidiosa surface attachment, biofilm formation and twitching motility. Appl Environ Microbiol. 2012;78(5):1321-1331.

54. Thankavel K, Shah AH, Cohen MS, et al. Molecular basis for the enterocyte tropism exhibited by Salmonella typhimurium type 1 fimbriae. J Biol Chem. 1999;274(9):5797-5809.

55. Real F, Oros J, Acosta F, et al. Pasteurellosis of gilthead seabream (Sparus aurata) in Gran Canaria Island, Spain. Bull Europ Ass Fish Pathol. 1997;17(5):153-157.

56. Toranzo AE, Barreiro S, Casal JF, et al. Pasteurellosis in culture gilthead seabream (Sparus aurata): first report in Spain. Aquaculture. 1991;99(1):1-15. 